\title{
A REORGANIZAÇÃO DO PCB EM ALAGOAS (1980-1982)
}

\section{Rodrigo José da Costa}

Hospedado no Hotel O.K. no Rio de Janeiro, em maio de 1979, o jornalista Nilson Miranda escreveu um bilhete no qual manifestava a sua alegria em retornar ao Brasil depois de um duro período de exílio na Europa:

Rio, 16 de maio 1979.

Antes mesmo de rever minha terra natal - uma saudade de 15 longos anos - desejo, através das páginas do "Desafio" expressar minha alegria e, ao mesmo tempo, manifestar um agradecimento à solidariedade recebida pela imprensa alagoana, em particular ao sindicato dos jornalistas e a equipe do jornal o "Desafio".

Bem como estender ao povo alagoano aquele abraço de quem há 15 anos não revê a terra natal.

Até breve daquele que nunca esqueceu Alagoas, sua gente, seu povo, em particular aos trabalhadores alagoanos.

Com o abraço do Nilson Miranda. ${ }^{2}$

Com uma barba densa, alguns fios brancos, o ex-vereador Nilson de Amorim Miranda, militante do Partido Comunista Brasileiro (PCB) em Alagoas, cujo mandato fora cassado com os primeiros expurgos decorrentes do Golpe Civil e Militar de 1964, havia retornado ao país na semana anterior, 15 anos depois de deixar o Brasil para fugir à prisão por questões de ordem política. Durante o exílio, Miranda viu seus cinco filhos crescerem sem ele, em um intervalo de tempo no qual se tornou sogro e avô. Aos 46 anos de idade, parecia mais moderado que o explosivo vereador da Câmara Municipal nos idos de 1964, quando teve de abandonar o estado 3 .

No exílio, estudou História em Paris e trabalhou como jornalista para uma cadeia de publicações de entidades sindicais ligadas aos trabalhadores. Conheceu toda a Europa e eventualmente tomou contato em Bruxelas com outro alagoano exilado, Vladimir Palmeira. Ainda hospedado no Rio de Janeiro, Nilson Miranda concordou em ser entrevistado por repórteres do jornal alagoano Desafio. A entrevista havia sido pedida ao seu irmão Haroldo Miranda, que estava presente no desembarque. No seu contato, Nilson Miranda evitou todo o tempo tratar de temas pessoais, para não envolver a família nos assuntos políticos.

Ao ser questionado se pretendia voltar a atuar politicamente, Miranda respondeu que pretendia primeiramente restabelecer os seus direitos e regularizar suas atividades

\footnotetext{
${ }^{1}$ Doutorando em História pela Universidade Federal de Pernambuco. Bolsista CNPq. Professor Auxiliar da Universidade Federal de Alagoas, Campus Arapiraca. E-Mail: <rodrigojosedacosta@gmail.com>.

2 "LUGAR de brasileiro é no Brasil. Voltou o primeiro alagoano exilado - Anistia: Os outros querem voltar". Desafio, Maceió, n. 77, 19 mai. 1979, p. 5.

3 "LUGAR de brasileiro...".
} 
profissionais, mas o retorno à militância política não estava de maneira alguma descartado. Porém, o caminho para uma atividade política saudável no país passaria obrigatoriamente por uma anistia. Mesmo beneficiado por um processo de abertura, o que importava mesmo, segundo ele, era a anistia ${ }^{4}$.

No decorrer da entrevista, Nilson relatou acerca de sua saída de Maceió no primeiro dia de abril de 1964, à noite. O governo de Luiz Cavalcante já havia começado as prisões em todo o movimento sindical ${ }^{5}$. Escondido na casa de amigos, depois de um mês deixara o estado para só retornar uma década e meia depois. Alguns desses amigos morreram enquanto esteve no exílio. Quando perguntado o que mais lhe dava saudades no exílio, Miranda afirmou que "o nordestino emigra por razões econômicas; fora de sua terra, ele tem saudades, agora, calcule quanta saudade ele sentirá se emigra por razões políticas. A dose é dupla. A verdade é que em 1964 o Brasil ficou pequeno para mim, mesmo esse Brasil de dimensões continentais"6.

Questionado sobre como via o movimento grevista dos trabalhadores no Brasil, ele foi categórico em afirmar que, em 15 anos, a classe operária sempre foi marginalizada. Todo o processo de desenvolvimento do Brasil, consistiu no achatamento dos salários. Citando a tese de Delfim Neto e outros de que "era hora de fazer crescer o bolo para depois dividir. O bolo cresceu e não dividiram. A coisa então foi ficando como uma panela de pressão sem válvula" ". Para o entrevistado, o movimento grevista era um indicativo de que os trabalhadores estavam defendendo a sua participação na vida social. Se eram responsáveis pela estabilidade econômica do país, seria justo que tivessem o seu papel na vida social.

Sobre a imagem do regime brasileiro no exterior, Miranda afirmou que naquele momento, era visto como uma tendência de abertura. Apesar de eleição indireta para governador, apesar dos biônicos, a imagem havia mudado. "Mudou muito em função das eleições passadas" ${ }^{8}$, quando a oposição recebera maior número de votos que o partido governista.

No caso da situação dos brasileiros exilados no exterior, ele citou que a angústia maior de todos era o desejo de regressar ao país. De Clodomir Morais, em Portugal, Francisco Julião, no México; Vladimir Palmeira, Miguel Arraes, Leonel Brizola, todos, enfim, queriam voltar. No fim da entrevista, perguntado sobre suas expectativas sobre o Governo Figueiredo, Nilson disse não esperar nada. Em sua opinião, o presidente poderia e deveria fazer o encontro que o presidente anterior, Ernesto Geisel, deixou de fazer, que era o encontro do Estado com a Nação. A questão econômica é também uma questão social e política. $\mathrm{O}$ país precisava urgentemente de uma

\footnotetext{
4 "LUGAR de brasileiro...".

${ }^{5}$ Sobre o governo Luiz Cavalcante e o Golpe Civil e Militar de 1964, ver: COSTA, Rodrigo José. O golpe civil-militar em Alagoas: o governo Luiz Cavalcante e as lutas sociais. Dissertação (Mestrado em História). Universidade federal de Pernambuco. Recife, 2013. MEDEIROS, Fernando Antonio Mesquita. Homo Inimicus: Igreja Católica, Ação Social Católica e discurso anticomunista em Alagoas. Maceió: EdUFAL, 2007.

6 "LUGAR de brasileiro...".

7 "LUGAR de brasileiro...".

${ }^{8}$ Miranda se refere às eleições legislativas de 1978, quando o partido de oposição legal ao Regime Militar, o Movimento Democrático Brasileiro - MDB, conseguiu eleger um número significativo de parlamentares.
} 
Assembleia Nacional Constituinte. O general Figueiredo poderia se propor a atender a esse interesse nacional. Se ele decidisse fazer isso, teria que começar pela anistia.

Em Alagoas, com o golpe de abril de 1964, os comunistas foram presos e perseguidos. As forças da repressão destruíram a redação do semanário editado pelo $\mathrm{PCB}$, o jornal A Voz do Povo, confiscando todos os documentos. O líder sindical e dirigente comunista Rubens Colaço foi o primeiro a sofrer com a repressão violenta dos golpistas alagoanos. Preso durante a madrugada do dia $1^{\circ}$ de abril, Colaço foi submetido a sessões de torturas. As prisões atingiram frontalmente a direção regional $e$ demais organizações intermediárias do $\mathrm{PCB}^{9}$. Foram presos intelectuais, operários, camponeses, estudantes com filiação política ou não. O Golpe desarticulou o PCB $e$ durante alguns meses a direção estadual não conseguiu se reunir, obrigando os principais dirigentes a sair do estado. Aos poucos os comunistas se rearticularam $e$ passaram a atuar com menos força na sociedade civil. O PCB, depois do golpe, se resumiu a um pequeno grupo de velhos militantes e alguns poucos jovens recrutados no movimento estudantil ${ }^{10}$.

Na década de 1970, o PCB alagoano ficou praticamente inativo, sem contato com a direção nacional - esta última exilada em Moscou - $e$ reduzido a poucos militantes com atuação esporádica apenas em momentos eleitorais, mas sem qualquer influência social. O partido ficou durante quase dez anos sem uma direção formalmente organizada para dirigir os poucos comunistas em Maceió e no interior ${ }^{11}$.

$\mathrm{O}$ processo de reorganização do $\mathrm{PCB}$ aconteceu após a anistia para os presos $e$ exilados políticos em 1979. A direção nacional foi quem reestruturou as atividades retomando os contatos, há muito perdidos, nos estados. Em Alagoas, o primeiro contato efetivo entre os poucos e dispersos comunistas ocorreu com a chegada do exílio de Nilson Miranda. Esse foi o marco zero no trabalho de retomada de contato entre os remanescentes e alguém com vínculos com a direção nacional ${ }^{12}$.

No decorrer do ano de 1980 os contatos foram restabelecidos entre o Comitê Central e a seção regional de Alagoas, trabalho esse que se deu durante quase dez anos ininterruptos ${ }^{13}$. O núcleo inicial constituído para reorganizar o PCB em Alagoas foi composto por ex sindicalistas, estudantes, alguns profissionais liberais $e$ jornalistas ${ }^{14}$.

Diante do exposto, é meu objetivo neste trabalho analisar a reorganização do PCB em Alagoas entre 1980 e 1982. A atenção recairá inicialmente nos dois processos paralelos que envolveram de um lado, a reorganização do Partido em nível nacional, com o retorno do Comitê Central o qual se encontrava exilado desde meados da década de 1970; de outro, as estratégias adotadas pelos comunistas alagoanos para a

${ }^{9}$ Cf. MAJELLA, Geraldo de. "Preservando a memória: a trajetória dos comunistas em Alagoas (19241991)". In: (org.). O PCB em Alagoas: documentos (1982-1990). Maceió: EdUFAL, 2010, p. 22.

${ }^{10}$ MAJELLA, "Preservando a memória...", p. 24-25.

${ }^{11}$ Cf. LESSA, Golbery. "Os principais momentos do PCB em Alagoas". In: SALDANHA, Alberto (org.). A indústria têxtil, a classe operária e o PCB em Alagoas. Maceió: EdUFAL, 2011, p. 105.

${ }^{12}$ Cf. MAJELLA, "Preservando a memória...", p. 25.

13 Cf. SALDANHA, Alberto. "O PCB alagoano depois de 1980: cultura comunista e mitos coesionadores". In: SALDANHA, A indústria têxtil...

${ }^{14}$ Cf. LESSA, "Os principais momentos...", p. 107-109. 
reestruturação da agremiação no estado. Antes da profunda atuação na campanha pela Anistia, as articulações para as eleições legislativas de 1978 foram um marco no trabalho da militância pecebista alagoana, ao mesmo tempo em que possibilitaram a entrada de um grupo de jovens estudantes os quais, juntamente com os antigos comunistas deram o passo decisivo para restabelecer a atuação política do Partido em Alagoas a partir do ano de 1980.

As fontes utilizadas neste trabalho tiveram o seu sustentáculo em dois acervos distintos, contudo, complementares. O primeiro compreende os documentos dos planos de organização e de campanha nos processos eleitorais do PCB alagoano, organizados e publicados por Geraldo Majella no livro $O P C B$ em Alagoas: documentos (1982-1990). O segundo grupo foi originário do Fundo Geraldo Majella disponível no portal Memórias Reveladas ${ }^{15}$. Assim como os documentos que foram compilados no livro, as fontes disponíveis neste fundo pertenceram durante muito tempo ao arquivo privado de Geraldo Majella, historiador alagoano e ex militante comunista na década de 1980. Na vigência do Projeto Memórias Reveladas ${ }^{16}$, em 2010, elas foram doadas ao Arquivo Público de Alagoas.

Também foram consultados alguns números do jornal Voz da Unidade, editado pelo PCB a partir de março de 1980, bem como algumas entrevistas realizadas com ex-militantes do PCB alagoano e livros de memória, publicados na última década.

\section{Desencontros}

Se a decretação da anistia e a consequente volta de muitos dos membros do Comitê Central exilados possibilitaram um reagrupamento dos comunistas do PCB em território nacional, ainda assim, o partido vivia um momento delicado. Se, em tese, sua política de superação do regime militar a partir da formação de uma ampla frente democrática seria cada vez mais coroada de êxito, os desdobramentos do processo de abertura iniciado na segunda metade da década de 1970, a emergência do Novo Sindicalismo e o surgimento de outros partidos políticos - que ao reivindicar a representação dos trabalhadores, se tornavam concorrentes do PCB, como o Partido dos Trabalhadores (PT) - além das baixas que o partido sofrera durante a ditadura, impuseram uma série de obstáculos cuja resposta deveria ser imediata.

As forças políticas e sociais vinculadas ao movimento operário e popular derrotadas em 1964, mesmo atordoadas, passaram a refletir sobre os motivos da derrota e sobre o que fazer para organizar e travar a luta de resistência. Para os agrupamentos que se encontravam à esquerda do $\mathrm{PCB}$ - como o PCdoB, a $\mathrm{AP}$ e a Polop -, o problema estava no fato de se depositar confiança demasiada no governo nacional burguês e de as massas não terem sido preparadas para resistir ao golpe de

\footnotetext{
${ }^{15}$ Disponível em: <http://www.an.gov.br/mr/>.

${ }^{16}$ O Centro de Referência das Lutas Políticas no Brasil, denominado "Memórias Reveladas", foi institucionalizado pela Casa Civil da Presidência da República e implantado no Arquivo Nacional com a finalidade de reunir informações sobre os fatos da história política recente do País. Em novembro de 2005, foi assinado o decreto regulamentando a transferência para o Arquivo Nacional dos acervos dos extintos Conselho de Segurança Nacional, Comissão Geral de Investigações e Serviço Nacional de Informações, até então sob a custódia da Agência Brasileira de Inteligência (ABIN). O Centro constitui um marco na democratização do acesso à informação.
} 
maneira organizada e armada ${ }^{17}$. Daí a convicção de que a resistência e a derrocada da ditadura teriam de ser pela via das armas e com respaldo popular amplo. Uma parte muito significativa do PCB também tendeu a seguir essa avaliação, o que se explicitou nos encontros preparatórios do VI Congresso, realizado em 1967, ao ponto de se gerarem diversas cisões ${ }^{18}$.

No entanto, para a militância que seguiu essa orientação, o drama iniciado em 1964 se transformou em tragédia, com a luta desigual travada contra o Estado entre 1969 e 1973. Na visão de Marcos Del Roio,

[...] a exacerbação da violência estatal e paramilitar, o reforço do corporativismo, o discurso ideológico pseudonacionalista e principalmente o predomínio do capital bancário/financeiro eram indícios de um processo de fascistização, que foi barrado pela oposição liberal burguesa e pela oposição popular (indiretamente auxiliadas pela crise energética mundial). ${ }^{19}$

Desde o início do período, a maioria do PCB defendia a unidade entre as forças populares $e$ a oposição liberal para derrotar a ditadura $e$ instaurar uma nova democracia a partir de uma assembleia constituinte. Ainda de acordo com o autor, essa posição ganhou força depois de 1974, "perante divisões no Estado e na burguesia diante da fascistização e o crescente descontentamento popular de tamanha exploração do trabalho e violência estatal" ${ }^{20}$.

No Estado, em particular nas Forças Armadas, havia uma posição favorável à permanência da situação de excepcionalidade e exacerbação do corporativismo $e$ outra - que ocupou o governo com o general Geisel - que se empenhava em garantir instituições estáveis, o que exigiria a cessação da perseguição política e cultural sistemática e a concessão de espaços efetivos para a oposição liberal e para a Igreja Católica. A oposição popular de esquerda marxista estava terrivelmente fragilizada por conta da repressão, a qual continuou atuando com denodo contra os comunistas até 1976, cujos efeitos foram devastadores. Com isso, a esquerda católica pode ocupar espaços maiores, pois tinha melhores condições de defesa e contava com o

${ }^{17}$ REIS FILHO, Daniel Aarão. A revolução faltou ao encontro: os comunistas no Brasil. São Paulo: Brasiliense, 1990.

${ }^{18}$ REIS FILHO, A revolução faltou ao encontro..., p. 47. O lapso temporal transcorrido entre o golpe e o VI Congresso realizado em 1967, marcou o período de fragmentação do PCB em uma série de miniorganizações que se multiplicaram pelos anos seguintes. Se, por um lado, o PCB atribuía ao "esquerdismo" a responsabilidade pelo golpe, para as correntes internas, as quais começavam a discordar da linha geral do Partido, pelo contrário, adviriam do "direitismo" as causas da derrota. Para os primeiros tratava-se de esconjurar os líderes nacionalistas e comunistas que quiseram ir longe demais. Para os segundos, era necessário fazer rolar as cabeças dos dirigentes do PCB, a de Prestes em particular. Sobre os acontecimentos decorrentes da fragmentação do PCB ver: GORENDER, Jacob. Combate nas trevas: a esquerda brasileira - das ilusões perdidas à luta armada. 4. ed. São Paulo: Ática, 1990.

${ }^{19}$ DEL ROIO, Marcos. "Prefácio". In: PINHEIRO, Milton (org.). O que resta da transição. São Paulo: Boitempo, 2014, p. 8-9.

${ }^{20}$ DEL ROIO, "Prefácio", p. 8-9. 
respaldo institucional da Igreja. Mesmo assim, a política de frente dos comunistas angariou frutos, e a pressão popular difusa deslocou uma área liberal para o campo da democracia, incluindo algumas lideranças intelectuais em particular ${ }^{21}$.

No começo da década de 1980, o debate em torno da questão democrática ressoou forte no interior do PCB. Muitos defendiam a manutenção da proposta de frente ampla contra a ditadura e combatiam a concepção instrumental da democracia adotada no passado. Para alguns de seus militantes, a organização havia se distanciado dos princípios revolucionários e perdido sua identidade de classe. Em vez de assumir o papel de vanguarda do proletariado, o PCB estava se transformando num partido reformista, próximo da social democracia ${ }^{22}$.

Maria Alice Carvalho aponta que, quando o PCB aprofundava sua orientação democrática em meio a um intenso movimento de massas contra o regime militar, era razoável supor que o acerto de sua política favorecesse a elaboração de uma práxis coerente com ela. Mas, na visão da autora, "o PCB não soube ganhar"23. E a experiência acumulada na luta por uma sociedade progressivamente mais justa $e$ democrática, se não se perdeu de todo - pois acabou incorporada como ponto de passagem obrigatório à reflexão de esquerda no Brasil - não lhe serviu como plataforma para sua própria refundação.

É assim que, em fins da década de 1970, o argumento democrático se desvencilhou da sua subordinação à questão nacional, estabelecendo-se a conquista das liberdades democráticas como foco central da luta comunista. Em maio de 1978 se consagrou a via eleitoral como "forma superior de luta" e, em novembro daquele mesmo ano, uma nova resolução política do Comitê Central sustentou que, para os comunistas, "luta pela democracia é parte integrante da luta pelo socialismo", sendo a frente antifascista indiferente aos interesses econômicos das forças que a compunham.

Muitos fatores colaboraram para a vitória, naquele momento, da concepção de democracia progressiva, considerando-se que tal concepção não era inteiramente estranha à Declaração de Março de 1958 nem ao VI Congresso, em 1967. Mas, em ambos, persistiu um viés terceiro-mundista, o que conferiu limites severos à nova identidade que a questão democrática fomentava entre a militância comunista.

Não obstante esses impasses, em 1980, houve o rompimento do secretário geral do PCB, Luís Carlos Prestes, o qual ocupara o cargo desde a década de 1940. Discordando da linha assumida pelo partido, Prestes, que se encontrava exilado em Moscou desde 1971, viu fortalecer-se a corrente antiprestista no interior da agremiação. O "Cavaleiro da Esperança" foi acusado por seus companheiros de ser "personalista, caudilho, autoritário e esquerdista" ${ }^{24}$.

\footnotetext{
${ }^{21}$ DEL ROIO, "Prefácio", p. 8-9.

${ }^{22}$ PANDOLFI, Dulce Chaves. "A trajetória de Luís Carlos Prestes". In: FERREIRA, Jorge \& REIS, Daniel Aarão. As esquerdas no Brasil: Revolução e democracia (1964...), volume 3. Rio de Janeiro: Civilização Brasileira, 2007, p. 236. Em 2014, o historiador Daniel Aarão Reis publicou a biografia do líder comunista, abarcando toda a sua trajetória política e pessoal ao longo de praticamente todo o século XX. Ver: REIS, Daniel Aarão. Luís Carlos Prestes. São Paulo: Companhia das Letras, 2014.

${ }^{23}$ CARVALHO, Maria Alice Rezende. "Breve história do 'comunismo democrático' no Brasil". In: FERREIRA, Jorge \& REIS, Daniel Aarão. As esquerdas no Brasil: Revolução e democracia (1964...), volume 3. Rio de Janeiro: Civilização Brasileira, 2007, p. 264.

${ }^{24}$ PANDOLFI, "A trajetória...", p. 237.
} 
Em março de 1980, Prestes, que havia retornado ao Brasil em outubro de 1979 após oito anos de exílio forçado, beneficiado com a decretação da anistia, elaborou uma "Carta aos Comunistas", criticando as posições "reformistas" assumidas pelo partido. Denunciava a falência da direção, responsabilizando-a pela prisão e morte dos dez membros do Comitê Central assassinados pelos órgãos policiais em 1974. Destituído do cargo de secretário-geral, que passou a ser ocupado por Giocondo Dias, Prestes, procurou, sem sucesso, o apoio da União Soviética. Em junho de 1980, juntamente com sua mulher, viajou a Moscou para apresentar suas divergências com os comunistas brasileiros. Em vão. O interlocutor privilegiado dos soviéticos era o $\mathrm{PCB}$, não mais Prestes.

De acordo com Anita Leocádia Prestes, convencido do abandono por parte da direção do PCB de seus objetivos revolucionários consagrados nos documentos partidários, Prestes, tendo compreendido que não havia condições para organizar de imediato um partido revolucionário no Brasil, iria dedicar os últimos dez anos de sua vida a difundir suas ideias, principalmente junto aos trabalhadores e aos jovens ${ }^{25}$. Ao mesmo tempo, procuraria participar, ao lado de seus apoiadores, da vida política nacional, com o objetivo de acumular forças e contribuir para a criação das condições propícias ao surgimento de organizações efetivamente revolucionárias, habilitadas a conduzir a realização das transformações necessárias ao advento do socialismo no país.

Prestes percorreu todo o Brasil a convite das mais diversas entidades sociais, de trabalhadores, de estudantes, de intelectuais, de políticos e de numerosos admiradores. Participou das principais campanhas eleitorais, procurando sempre dar apoio aos candidatos comprometidos com as causas populares e dispostos a contribuir para o avanço real da democratização do país.

Ao empenhar-se na luta pela efetiva democratização do Brasil, ao denunciar a permanecia do regime ditatorial durante o governo Figueiredo - repelindo as teses dos liberais e da direção do PCB de que se estariam atravessando um período de "transição" para a democracia -, Prestes insistia na continuidade do "poder militar", ao qual voltaria a referir-se repetidas vezes durante aqueles anos ${ }^{26}$.

O rompimento de Prestes com o PCB pode ser acompanhado no semanário Voz da Unidade, editado pelo partido a partir de março de 1980. Em seu primeiro número, o jornal traz uma matéria na qual relatou uma palestra proferida pelo até então Secretário Geral na cidade de São Paulo, oportunidade em que Prestes discorreu sobre a questão da reforma partidária ${ }^{27}$. Ele analisou a situação dos partidos oposicionistas em formação, detendo-se em especial no papel que o PMDB - como partido que melhor expressava a diversidade de interesses inscrita na frente ampla poderia desempenhar na luta pela democracia no País. Para Prestes, o objetivo visado pelo regime com a reformulação partidária era o de dividir as oposições: uma

\footnotetext{
${ }^{25}$ PRESTES, Anita Leocádia. "Luiz Carlos Prestes e a luta pela democratização da vida nacional após a anistia de 1979". In: PINHEIRO, Milton (org.). O que resta da transição. São Paulo: Boitempo, 2014, p. 119-120.

${ }^{26}$ PRESTES, "Luiz Carlos Prestes...", p. 119-120.

27 "PRESTES: frente única no combate à ditadura". Voz da Unidade. São Paulo, n. 01, 30 mar. a 05 abr. 1980, p. 7.
} 
manobra que se combinava com uma "desavergonhada corrupção, que faz o Sr. Maluf operar o milagre de transformar a minoritária Arena no majoritário PDS". O líder comunista, entretanto, lembrou que a ditadura "está enganada se pensa que basta dividir os políticos para dividir as massas" 28 .

Manifestando-se defensor de uma constante preocupação com a unidade das oposições, Prestes colocou-se não só a favor da participação de todos os partidos em formação - PTB, PT e PP, com suas características específicas - na frente de luta contra o regime, como também da "unificação da classe operária para atuar num partido revolucionário". Com isso, a classe operária interviria como fator decisivo na "frente única de luta contra a ditadura", formada não apenas com os quadros da esquerda, mas com "todos os que desejarem ser nossos aliados nessa luta" ${ }^{29}$.

Com essa perspectiva, Prestes defendeu firmemente a legalização do PCB, afirmando ser o mesmo o "partido que sempre lutou pela democracia no país"30. Para isso, era preciso organizar e unir as massas numa campanha pela revogação da Lei de Segurança Nacional, para que o partido pudesse ser legalizado. Coincidindo nesse ponto com diversas declarações de líderes do PCB, Prestes entendia a luta pela legalização do partido como o resultado de um amplo trabalho político de massas:

\begin{abstract}
A legalidade não se consegue de joelhos. Ela tem que ser conquistada nas ruas, como em 1945. Se isso ocorrer, o partido poderá rapidamente organizar todas as forças de luta contra a ditadura, e formar um bloco para conquistar o poder e implantar uma democracia política, econômica e social, abrindo o caminho para o socialismo. ${ }^{31}$
\end{abstract}

Tal campanha teria, assim, que ser colocada na ordem do dia pelos comunistas e pelo conjunto das forças democráticas. Com ela, avançaria o processo de democratização na sociedade brasileira. Pois, como lembrou Prestes, concordando com as posições dos membros do Comitê Central do PCB, "a atual ditatura não pode mais ser chamada de fascista, depois da revogação do AI-5 e da conquista da anistia. Entretanto, a ditadura preserva o fundamental de sua essência”, devendo, por isso, ser combatida por um amplo movimento de massas ${ }^{32}$.

\footnotetext{
28 "PRESTES: frente única...", p. 7.

29 "PRESTES: frente única...", p. 7.

30 "PRESTES: frente única...", p. 7. Grifos meus. Dulce Pandolfi aponta que ao longo da história do PCB houve uma tendência a reelaborar a memória partidária no sentido de valorizar a opção pela luta democrática, principalmente depois da Declaração de Março de 1958 e do V Congresso de 1960, em detrimento de linhas políticas insurrecionais adotadas quando da "Intentona" de 1935 e do período compreendido pela perda do registro eleitoral em 1947, intensificadas depois do Manifesto de Agosto de 1950, cuja revisão depois de 1954 vai culminar na concepção de revolução em duas etapas: a primeira, nacional-democrática e a segunda socialista. Para um aprofundamento da questão, ver: PANDOLFI, Dulce. Camaradas e companheiros: História e memória do PCB. Rio de Janeiro: Relumé Dumará, 1995. SEGATTO, José Antonio. Reforma e revolução: as vicissitudes políticas do PCB (19541964). Rio de Janeiro: Civilização Brasileira, 1995.

31 "PRESTES: frente única...", p. 7.

32 "PRESTES: frente única...", p. 7.
} 
Já no número seguinte, diante da controvérsia criada com a publicação por parte de Prestes da "Carta aos Comunistas", os dirigentes emitiram uma declaração onde defendiam a legitimidade do Comitê Central, condenavam o golpismo $e$ manifestavam confiança na política de intervenção de massas adotadas pelo $\mathrm{PCB}^{33}$.

Admitindo a existência de "divergências políticas de fundo" entre as atuais posições do secretário geral $e$ a linha do $\mathrm{PCB}$, os dirigentes reafirmaram a legitimidade do Comitê Central e lamentavam a forma "anárquica" e pouco democrática pela qual Luís Carlos Prestes vinha colocando em discussão a política adotada desde o VI Congresso, realizado em 1967. No texto da "Declaração" afirmaram que:

Um partido comunista é inconcebível sem direção. Quando o camarada Prestes considera falida e inexistente, na prática a atual direção do PCB e conclama os comunistas e as bases do Partido a promoverem sua dissolução, desfecha, queira ou não, um golpe contra o próprio PCB.

Assinada por Giocondo Dias, Salomão Malina, Teodoro Mello, Hércules Correia e Armênio Guedes a declaração dos dirigentes comunistas insistia em que essa linha visava "orientar a ação do PCB no rumo de uma política de massas", tratando-se, portanto, de uma concepção que condenava o golpismo, o "esquerdismo", a busca de perigosas tensões como método obsessivo de um suposto caminho revolucionário. Segundo os dirigentes comunistas, ao contrário, a concepção de frente única defendida por Prestes supunha que a derrota da ditadura implicava necessariamente a constituição de um poder antimonopolista e antilatifundiário, o que, em sua opinião, não correspondia à realidade dos fatos.

Manifestando-se frontalmente contrários ao "liquidacionismo", os dirigentes recusavam-se a considerar válida a proposta da autodissolução do Comitê Central; enfatizavam que a luta pela legalidade do PCB era inseparável da realização do VII Congresso - instância onde tais divergências deveriam ser resolvidas - e não abdicavam da possibilidade de "dar à discussão um encaminhamento e uma conclusão democráticos" ${ }^{34}$.

Na polêmica "Carta", o então Secretário-Geral pregava a dissolução das direções e considerava superada orientação política do VI Congresso ${ }^{35}$. Constatando a existência de "uma séria crise já flagrante e de conhecimento público" no interior do Partido, Prestes pretendeu denunciar o que considerava ser a "falência de sua direção", a quem, acusava de "oportunista, carreirista, reboquista e sem princípios" 36.

A carta de Prestes acabou por ser amplamente reproduzida, na íntegra ou em partes, pela imprensa periódica do país durante os dias que se seguiram a sua publicação. Ao mesmo tempo em que questionava a legitimidade do atual Comitê

\footnotetext{
33 "DIVERGÊNCIAS: comunistas respondem ao Secretário geral". Voz da Unidade, São Paulo, n. 2, 10 a 16 abr. 1980, p. 3.

34 "DIVERGÊNCIAS: comunistas respondem...", p. 3.

35 "A CARTA de Prestes aos comunistas". Voz da Unidade, São Paulo, n. 2, 10 a 16 abr. 1980, p. 4.

36 "A CARTA de Prestes...", p. 4.
} 
Central, apelava aos companheiros "para que tomem os destinos do movimento comunista em suas mãos", rompendo com a passividade e "rebelando-se contra as arbitrariedades e os métodos mandonistas da direção". Além disso, Prestes buscava manifestar-se sobre a questão da legalidade do PCB e sobre a realização do seu VII Congresso, afirmando que a orientação política do $\mathrm{PCB}$ estava superada e não correspondia à realidade do movimento operário e popular daquele momento.

Cerca de seis semanas depois, Prestes foi afastado da Secretaria e Giocondo Dias foi eleito para ocupar o mais alto cargo na hierarquia do $\mathrm{PCB}^{37}$. Após declarado vago o cargo de Secretário-geral, ocupado por Prestes por quase 4 décadas, Dias foi aclamado novo dirigente máximo dos comunistas brasileiros. Segundo os dirigentes, o ex Secretário-geral do PCB, o qual desde 1943 ocupava o cargo, tendo sido eleito na famosa Conferência da Mantiqueira, não foi reconduzido por não ter atendido a várias convocações do órgão dirigente máximo para discussões, o que configurava, na prática, a "vacância do cargo", agora formalizada.

Em documento divulgado na ocasião, cinco dos principais dirigentes políticos comunistas - Giocondo Dias, Salomão Malina. Teodoro Mello, Hércules Correa e Armênio Guedes - prometeram uma crítica "mais circunstanciada" às posições assumidas por Prestes ${ }^{38}$. O documento elaborado pela Direção remanescente, intitulado "Luta por liberdades não é mero expediente tático" afirmava que:

Os dirigentes comunistas eleitos pelo VI Congresso para o Comitê Central do $P C B$, reuniram-se para discutir as críticas que lhes foram feitas por seu companheiro Luís Carlos Prestes, em carta aberta difundida em folheto e transcrita pela imprensa em começos de abril passado. Convidado a participar da reunião, ocasião em que poderia discutir democraticamente e fundamentar seus pontos de vista, o companheiro Prestes recusou-se a comparecer. Depois de discutirem a carta aberta de Prestes e apreciarem os últimos acontecimentos políticos do país, os dirigentes comunistas, decidiram elaborar e tornar públicos os documentos "Sobre a situação política atual" e "Sobre a Carta aos Comunistas do companheiro Luís Carlos Prestes". Para efeito de identificação destes e de futuros pronunciamentos, seus autores resolveram adotar a denominação de Coletivo De Dirigentes Comunistas. ${ }^{39}$

$\mathrm{Na}$ ótica do novo secretário-geral do PCB, as mudanças ocorridas no partido teriam o benéfico efeito de ampliar a democracia interna e a prática da direção

37 "GIOCONDO é eleito novo secretário comunista". Voz da Unidade, São Paulo, n. 8, 22 a 28 mai. 1980, p. 1.

38 "COMUNISTAS afastam Prestes da Secretaria". Voz da Unidade, São Paulo, n. 8, 22 a 28 mai. 1980, p. 8.

${ }^{39}$ Este trecho do documento se encontra reproduzido na matéria citada na nota anterior. 
coletiva, permitindo uma participação mais coerente dos comunistas na vida política nacional ${ }^{40}$.

A súmula das divergências de Prestes com o PCB diziam respeito sobretudo ao encaminhamento da revolução socialista, abandonada pelo Comitê Central na visão do "Cavaleiro da Esperança", o que, por conseguinte, acarretava no não questionamento da dominação do Capital. Não à toa, Giocondo Dias e seus partidários eram acusados de um "antissovietismo envergonhado", enquanto Prestes defendia o apoio sem reservas à URSS e ao campo socialista ${ }^{41}$.

$\mathrm{Na}$ avaliação do regime democrático, os primeiros eram favoráveis a uma "democracia pura", o segundo insistia no seu "conteúdo de classe". Para uns, a ditadura já era coisa do passado, estendiam a mão para o ditador de turno, o general Figueiredo, e conchavam com ele a legalização do PCB. Para Prestes, a ditadura continuava de pé, o país permanecia sob a tutela dos militares, e a legalização do Partido só podia ser concebida no horizonte das lutas sociais e como resultado de suas conquistas. Do ponto de vista imediato, ao passo que o $\mathrm{CC}$ defendia o caminho eleitoral e parlamentar, apoiado numa ampla frente social e política, "a reboque da burguesia liberal", os partidários de Prestes sustentavam a alternativa das "lutas de massa", com a unificação das "forças de esquerda" no contexto de uma frente democrática da qual seriam excluídos os representantes dos "monopólios". No plano da organização partidária, os homens do CC não só negavam uma "autocrítica profunda dos métodos de organização", como insistiam na existência de uma "atividade terrorista na condução da luta interna" 42.

Foi sem dúvida um primeiro semestre agitado em 1980, quando o PCB, a duras penas, conseguiu dar os primeiros passos para sua reinserção na cena política nacional. Em Alagoas este processo de reaglutinação da militância pecebista havia se iniciado um pouco antes, mas, nem por isso ela deixou de apresentar instabilidades, seja o eco das disputas irradiadas do Comitê Central, seja os problemas de ordem local os quais veremos a seguir.

\section{Encontros}

Passeando pela vizinhança numa tarde de inverno de 1979, o estudante secundarista Geraldo de Majella se surpreendeu ao se deparar com um senhor, reconhecido por ter estampado a capa dos jornais recentemente. Retratado como o primeiro alagoano a retornar do exílio, Nilson Miranda, ao ser interpelado pelo jovem demonstrou um pouco de receio quanto à abordagem, porém, à medida que aquele se apresentou como vizinho de Geraldo Melo, assim como de Rubens Colaço, os dois antigos militantes do PCB em Alagoas - da mesma maneira que o fora o próprio Miranda - o encontro perdeu a sua tensão inicial e a convite de Nilson, os dois mantiveram uma conversa que enveredou pelo restante daquela tarde $e^{43}$.

\footnotetext{
40 "O GOLPISMO só nos afasta das amplas massas". Voz da Unidade, São Paulo, n. 9, 29 mai. a 04 jun. 1980, p. 8-9.

${ }^{41}$ REIS, Luís Carlos..., p. 417.

${ }^{42}$ REIS, Luís Carlos..., p. 418.

${ }^{43}$ Entrevista de Geraldo Majella Fidélis de Moura Marques, concedida ao autor em 23/07/2014.
} 
Apesar de jovem, Geraldo Majella àquela altura já mantinha uma militância significativa no movimento estudantil secundarista de Maceió. Proveniente de Anadia, cidade do interior alagoano, era um jovem estudante cujo contato com assuntos políticos se dera através da leitura de periódicos da imprensa alternativa ${ }^{44}$, a exemplo do jornal carioca $O$ Pasquim, como também o jornal Movimento. O acesso a esses periódicos lhe havia sido facultado através da vivência com Sebastião Barbosa de Araújo, ex-deputado estadual pelo Partido Social Progressista (PSP), que militara pelo PCB antes de 1964.

É o próprio Majella que recorda que num momento posterior outras leituras foram sendo incorporadas, os romances Pessach de Carlos Heitor Cony, a trilogia Subterrâneos da Liberdade de Jorge Amado e, por fim, o livro Memórias do Cárcere de Graciliano Ramos ${ }^{45}$. Um momento em particular rememorado, foi quando Sebastião Araújo ofereceu ao jovem estudante o livro Manifesto do Partido Comunista de Karl Marx e Friedrich Engels. Paulatinamente, Majella tomava um contato cada vez maior com a cena política de Maceió, em um momento no qual os debates sobre o rumo da Ditadura Militar, o processo de abertura política e o restabelecimento do regime democrático se tornavam cada vez mais frequentes $e$ intensos.

Em meados de 1977, quando começaram as movimentações pelas eleições para o senado, a serem realizadas no ano seguinte, Majella pôde manter um contato mais efetivo com antigos militantes do PCB em Alagoas, todos mobilizados na campanha de José Moura Rocha na disputa por uma cadeira no legislativo federal.

Os pouco mais de treze anos de Ditadura vividos até aquele momento impuseram obstáculos significativos aos pecebistas alagoanos. Dispersos e sem uma organização formal, a atuação dos comunistas e, acima de tudo, sua mobilização, foram se tornando rarefeitas diante da escalada repressiva do regime militar. Com a perseguição sofrida, muitos dos militantes das décadas de 1950 e 1960 e, principalmente, depois de 1964, saíram de Alagoas e os que permaneceram estiveram frequentemente sob a vigilância dos órgãos policiais locais.

É o caso, por exemplo, de Rubens Colaço. Dirigente comunista em Alagoas desde os anos 1950, Colaço foi presidente do Sindicato dos Rodoviários e secretário do

\footnotetext{
${ }^{44}$ Durante os anos de governo militar - notadamente durante a década de 1970 - proliferou no Brasil um tipo de imprensa que ficou conhecida como imprensa alternativa. Eram jornais de formato tabloide ou mini tabloide, muitas vezes de tiragem irregular, alguns vendidos em bancas, outros de circulação restrita, e sempre de oposição. Durante a ditadura, esses jornais questionaram o regime, denunciaram a violência e a arbitrariedade, expressando uma opinião e uma posição de esquerda num país que praticamente havia suprimido quase todos os canais de organização e manifestação política de oposição. A imprensa alternativa congregava jornais de vários tipos: a) jornais de esquerda (que se vinculavam tanto a jornalistas de oposição quanto aos partidos e organizações políticas clandestinas); b) revistas de contracultura (que reuniam intelectuais e artistas "alternativos" ou "malditos" - os que produziam fora do esquema comercial); e c) publicações de movimentos sociais (englobando nesse campo o movimento estudantil, os movimentos de bairro e, principalmente, um tipo especifico de imprensa alternativa - aquela vinculada a grupos de minorias políticas, como a imprensa feminista, a chamada "imprensa negra", os jornais de grupos homossexuais organizados, as publicações indígenas $e$ etc. Para mais informações sobre a imprensa alternativa ver: KUCINSKI, Bernardo. Jornalistas e revolucionários: nos tempos da imprensa alternativa. São Paulo: Scritta, 1991.

${ }^{45}$ Entrevista de Geraldo Majella Fidélis de Moura Marques, concedida ao autor em 23 jul. 2014.
} 
Comando Geral dos Trabalhadores (CGT) no estado. Preso diversas vezes pela polícia política local ${ }^{46}$, desempenhara militância significativa nos meios operários durante grande parte do período liberal-democrático inaugurado em 1946 e, juntamente com os irmãos Nilson e Jayme Amorim de Miranda ${ }^{47}$, integrava a direção local do PCB quando da deflagração do golpe em 1964.

A relação entre Colaço e Majella se estreitou de forma que os dois passaram a conviver diariamente. Para além dos encontros com Nilson Miranda e Rubens Colaço, um terceiro, com Cícero Péricles de Carvalho, estudante de Economia, recém retornado da Europa, seria um dos passos na reestruturação PCB em Alagoas. Os outros passos consistiram em aglutinar a militância dispersa, o restabelecimento do contato com o Comitê Central e, acima de tudo, o recrutamento de novas forças que engrossassem as fileiras do Partido. Pelos menos é esse o tom tanto do depoimento pessoal de Geraldo Majella como o de Rubens Colaço ${ }^{48}$. Esse núcleo reorganizador também contou com José Graciano, Geraldo Oliveira, Antonio Omena, Mário Correia da Silva, e Sebastião Barbosa de Araújo ${ }^{49}$.

$\mathrm{O}(\mathrm{r}$ ) estabelecimento destes contatos, ponto de partida para a retomada da atividade do Partido também aparece no primeiro documento oficial do PCB alagoano datado daquela conjuntura. O "Balanço histórico" do ano de 1982 retrata a reorganização da agremiação como um encontro entre a geração atuante no PCB antes do Golpe com uma nova, composta em sua maioria de estudantes, cujo ingresso no partido em fins da década de 1970 possibilitou a reinserção dos comunistas no cenário político que se desenhava ${ }^{50}$.

${ }^{46}$ Para mais informações sobre a atuação da polícia política em terras alagoanas, ver: COSTA, Rodrigo. "Inimigos de estado: trabalhadores, comunistas e polícia política em Alagoas". In: XII Encontro Estadual de História da ANPUH/RS, 11-14 ago. 2014. São Leopoldo: ANPUH, 2014, p. 1-17.

47 Jaime Amorim de Miranda [1926-1975] nasceu em Maceió, foi jornalista e advogado. Enquanto estudava direito, foi secretário-geral do PCB em Alagoas, diretor do semanário comunista $A$ Voz do Povo. Foi preso em Recife e transferido para Maceió, onde ficou mais de um ano preso. Isso ocorreu durante o governo Arnon de Mello. Representou os comunistas alagoanos, em 1960, no V Congresso do PCB, sendo eleito para a direção nacional. Nas eleições de 1961 foi candidato a deputado estadual, ficando na primeira suplência. No dia $1^{\circ}$ de abril de 1964 , o jornal A Voz do Povo foi destruído, seus bens foram furtados, seus colaboradores foram presos, inclusive o diretor-geral, Jaime Miranda. Ao sair da prisão, não demorou muito tempo em Maceió; entrou na clandestinidade, indo morar no Rio de Janeiro com a família. Realizou algumas viagens internacionais como dirigente nacional do PCB, mas em 1975 foi sequestrado pelos órgãos de repressão. Nunca mais foi visto. Faz parte da relação dos desaparecidos políticos do Brasil. Nessa época integrava a Comissão Executiva do Comitê Central do PCB. Nilson Amorim de Miranda [1933] nasceu em Maceió. Jornalista e radialista, ex editor do semanário A Voz do Povo, ex-vereador de Maceió pela legenda do Partido Social Progressista - PSP. No final da década de 1950 trabalhou para fundar o Sindicato dos Radialista de Alagoas e foi o seu primeiro presidente. Quando eclodiu o golpe militar em abril de 1964, entrou na clandestinidade, tendo de evadir-se de Alagoas, pois passou a ser procurado pela polícia. Para mais informações sobre alguns dos militantes políticos da família Miranda, ver: MAJELLA, Geraldo. "Comunismo em família". Novos Rumos, vol. 1, 2005, p. 60-64.

${ }^{48}$ MAJELLA, Geraldo. Rubens Colaço - paixão e vida: a trajetória de um líder sindical. Recife: Edições Bagaço, 2010, p. 196.

${ }^{49}$ MAJELLA, "Preservando a memória...", p. 28.

50 "BALANÇO Histórico". In: PCB em Alagoas: Documentos (1982-1990). Maceió: [s. n.], 2011, p. 3138. 
Este documento também traz um balanço importante da situação vivida pelo PCB alagoano a partir da instauração da Ditadura em 1964. Logo nas primeiras horas do Golpe no estado, foram presos comunistas, trabalhistas, sindicalistas e trabalhadores. Os golpistas vinham sendo mobilizados e contaram com o integral apoio do governador Luiz Cavalcante, articulador do golpe na Região Nordeste. Por seu lado, o PCB, o qual vinha numa linha de crescimento político e organizacional, com o golpe se desorganizou. O Comitê Estadual e os seus principais dirigentes ficaram imobilizados; uns estavam presos, e os que não estavam não conseguiram manter nenhum tipo de atuação. O historiador Dirceu Lindoso, um dos intelectuais $e$ dirigente estadual, foi demitido do emprego quando se encontrava na prisão, $e$ sem condições de sobrevivência em Maceió, dadas as circunstâncias, viu-se obrigado a morar no Rio de Janeiro ${ }^{51}$.

$\mathrm{O}$ trabalho de reorganização do partido nos meses que se seguiram àquele abril de 1964 teve início efetivamente em 1965, após saírem da prisão os principais dirigentes. Jayme Miranda, secretário político, Lindoso, o operário João Moura e Rubens Colaço foram os últimos dirigentes pecebistas a serem soltos entre os presos políticos. Os que ficaram continuaram o árduo trabalho de reorganização do PCB, estruturação de bases de bairros, fábricas, estudantes, e em vários municípios alagoanos ${ }^{52}$.

A participação nas eleições de 1970 foi a última tentativa que o PCB teve com a expectativa de eleger um parlamentar. O candidato a vereador, Eduardo Davino, então dirigente do Sindicato dos Petroleiros de Alagoas, teve a candidatura cassada, foi afastado da diretoria do sindicato $e$ ainda teve os direitos políticos cassados por dez anos ${ }^{53}$. Para uma organização que já vinha sofrendo baixas voluntárias, tornavase cada vez mais preocupante a ação dos comunistas enquanto organização que resistia à Ditadura. Depois do Ato Institucional n. ${ }^{\circ} 5$, ficou cada vez mais restrito o campo de atuação. Além dos problemas causados pela repressão, também houve a perda de jovens militantes, estudantes em particular, para os agrupamentos de esquerda criados para iniciar a luta armada. As bases operárias eram cada vez mais raras, ficando o campo de atuação do $\mathrm{PCB}$ reduzido ao movimento estudantil basicamente. Em meados da década de 1970, as ligações com a direção nacional foram cortadas, o restabelecimento do contato só foi possível em 1980.

Mesmo com o clima de terror, o qual imobilizou os setores mais progressistas da sociedade, a atuação se deu de forma ativa nas entidades trabalhistas, ora criando sindicatos rurais (Anadia, Coruripe, Capela, Penedo etc.) juntamente com os setores não conservadores da Igreja Católica, ora dirigindo, como força hegemônica, o CGT (Comando Geral dos Trabalhadores) e o PUA (Pacto de Unidade e Ação), refletindo seu trabalho organizado em sindicatos (Arrumadores, Estivadores, Conferentes, Ferroviários, Rodoviários, Têxteis, Açúcar etc.) e Associações Profissionais (Portuários etc.) O golpe lacerante sofrido foi especialmente sentido no movimento sindical, onde as ações foram dificultadas.

Em determinado trecho do documento, é mencionado que o recuo do Partido se deu "por conta à sua escassa bagagem teórica e sua diminuta estrutura

\footnotetext{
${ }^{51}$ MAJELLA, "Preservando a memória...”, p. 29.

${ }^{52}$ MAJELLA, Rubens Colaço..., p. 178.

${ }^{53}$ MAJELLA, "Preservando a memória...", p. 24.
} 
organizativa" 54 . Vivendo num quadro desfavorável, a partir dessa data, houve um declínio contínuo em termos de organização interna e de força social. Mesmo conseguindo realizar uma Conferência Estadual, no final de 1967, com 18 delegados eleitos nas bases, o Partido em Alagoas não conseguiu, após este evento, dar dinamicidade, levar à prática a linha do Partido.

As quedas ocorridas em 1974, atingindo quase toda a direção nacional, diminuíram as chances de uma recuperação imediata. A inexistência de uma direção capaz - que não conseguiu continuar o trabalho no movimento sindical, estudantil $e$ camponês -, a imigração dos quadros mais ativos e a perda de contato com a direção nacional em 1971, fizeram com que o Partido fosse declinando na sua força até atingir um ponto próximo à letargia, quando um reduzido número de militantes mantivera em suas mãos a responsabilidade do que chamavam "direção". Tratava-se, na verdade, de um ínfimo grupo de pessoas, sem nenhuma vinculação com o movimento social (sindicatos, associações, clubes, universidades), que vivia de lembranças de um passado distante.

Segundo a caracterização feita no documento,

[...] o PCB, que sempre foi em Alagoas um pequeno partido de quadros e que atuava com efetividade no movimento de massas, teve refletido nos seus militantes o peso dos anos. Envelheceram seus quadros e não houve política de renovação. Muitos e bons militantes do Partido preferiram emigrar ou tiveram de sair de Alagoas.

Esse trecho é revelador de uma tônica que se expressará em outros documentos futuros, e que também dá conta das diversas tensões as quais volta-e-meia ocuparão os comunistas alagoanos: os embates entre as duas gerações responsáveis pela reorganização da agremiação. De um lado, os "velhos", formados em moldes "stalinistas", acostumados com a atuação em condições políticas das mais adversas, ainda que posteriormente adaptados às transformações ocorridas na linha política a partir da metade da década de 1950; do outro, uma geração de jovens, ainda sem um aprofundamento da sua experiência política sem, no entanto, estarem dispostos a ficar à mercê dos antigos. Menções, ainda que breves, as estas tensões geracionais são relatadas neste mesmo documento.

Durante o período que cobre os anos de 1968 a 1982, a atuação do PCdoB possibilitou a este último tornar-se força hegemônica na esquerda alagoana. Primeiro, ao fundir-se com a AP (Ação Popular), que era um grupo radical oriundo dos meios católicos e atuante no movimento estudantil; segundo, quando expande suas atividades para outras áreas do movimento popular e da sociedade civil (Associações de Moradores, Movimento Sindical, Sociedade de Direitos Humanos, União de Mulheres e Tendência Popular do PMDB). Na ótica pecebista, "pelo seu dinamismo, reflexo de sua composição fortemente de classe média estudantil, onde se implantou e se estendeu, o PCdoB cresceu e ocupou espaço" ${ }^{55}$. No final deste mesmo período

\footnotetext{
54 "BALANÇO Histórico", p. 31.

55 "BALANÇO Histórico", p. 32.

SAECULUM - Revista de História [36]; João Pessoa, jan./jun. 2017.
} 
(1980-82), o Partido dos Trabalhadores tentava sua organização em Alagoas, conseguindo absorver antigos militantes do PCB.

Se os anos transcorridos desde a implantação da Ditadura em 1964 haviam trazido uma série de consequências negativas para o PCB, o começo da década de 1980, porém prometia uma virada no seu destino. Diferentemente do final da década de 1960 e início dos anos 70, quando a inércia e a incapacidade política de sua organização perderam a parte mais ativa da juventude para organizações de extrema esquerda (PCBR, VAR Palmares, PCR), desfalcando o Partido de futuros quadros, o quadro começava a se alterar. Coincidindo com a fase de redemocratização (liberdade de imprensa, anistia etc.), na qual se inseria o aparecimento da Voz da Unidade, jornal legal do Partido, e "quando a sociedade brasileira acordava de uma longa noite de fascismo", o PCB em Alagoas recebia novas adesões.

Novamente, a alusão ao encontro de gerações:

Esse acontecimento dá um novo impulso ao Partido e voltam à organização antigos militantes afastados por motivos vários. Ao procurar o PCB, um grupo de jovens, ainda que em número reduzido para as nossas necessidades, comprovaria a validade da linha do Partido a nível nacional (defesa do calendário eleitoral, frente democrática, unidade do movimento sindical etc.), ainda que o Partido quase inexistisse em Alagoas.

Com requintes de ironia, uma nova alusão ao choque geracional é trazida à tona: a entrada de novos militantes, aliada ao crescimento das atividades políticas, fez com que se abrisse um processo de luta interna: primeiro, devido à recusa de alguns militantes em não participar do movimento político, contrariando inclusive a linha do $\mathrm{PCB}$ e, consequentemente, não permitindo o crescimento da organização, resistindo inclusive à reorganização do Partido; segundo, refletindo a crise nacional do Partido, muitos se agarravam a dogmas para não permitir que o debate, que se travava a nível nacional, chegasse com vida ao seio da organização. Defendiam a posição de que o Partido deveria ser composto por "poucos e bons", não compreendendo a luta dos comunistas para tornar o PCB uma organização legal e de massas. Essa concepção de partido de "poucos e bons" é suficientemente clara para identificar que os seus defensores tinham um conceito de partido - ou mais que isso, de PCB - forjado principalmente quando da legalização do Partido, em 1945.

Essa querela teve seu fecho numa reunião ampliada, realizada em Maceió em outubro de 81, quando 16 camaradas representando cerca de 50 companheiros se reuniram pela primeira vez em mais de 14 anos, para renovar a direção e encaminhar novas propostas. Alguns camaradas da antiga direção, não acatando as decisões do ampliado, se desligaram das atividades de Partido, assumindo uma postura de críticas pessoais, mas não de confronto. A nova direção incorreu no erro de não continuar o debate político com esses camaradas, ajudando assim para o distanciamento ${ }^{56}$.

56 "BALANÇO Histórico", p. 33. 
Os anos transcorridos desde o fechamento do Regime, em 1968, até o momento inicial de reorganização, trouxeram uma mudança na composição social do Partido. Se antes a organização compunha-se de base trabalhadora manual, naquele momento de reestruturação a composição havia se tornado mais heterogênea, revelando a predominância de elementos oriundos de setores não operários (funcionários públicos, estudantes, professores etc.).

A essa constatação das dificuldades vividas no seio do Partido ao longo dos, então, dezesseis anos de Ditadura, somava-se outra de igual pesar: a situação presente não era das melhores:

Por sua inexperiência, o Partido não teve um plano definido, com metas e prioridades para os diversos setores de nossa sociedade. Uma tentativa de plano de ação foi dissolvida pela dinâmica da campanha eleitoral.

Nossa intervenção no movimento sindical é inexpressiva. Alguns camaradas participam de seus sindicatos de forma isolada e assim se apresentaram nas comemorações do $1^{\circ}$ de maio de 1981 e 82. Nossa participação no $1^{\circ}$ ENCLAT foi desastrosa. Companheiros de militância reconhecida se desentenderam publicamente sobre como encaminhar os trabalhos do $1^{\circ}$ ENCLAT, reforçando a imagem do PCB em Alagoas como partido dividido e sem comando. $O 2^{\circ}$ ENCLAT seguiu o $1^{\circ}$ em intervenção negativa. Não aprendemos com o $1^{\circ}$ ENCLAT, não fizemos um balanço $e$ tivemos uma atuação apagada, deixando para o PT e o $P C d o B$ o comando da programação e ações. Não levamos nossos camaradas para o Encontro, de forma a participar defendendo a linha do Partido para o Movimento Sindical. Não levamos nossa imprensa (Correio Sindical, Voz da Unidade, liuros) nem nossa presença organizada. Como resultado, Alagoas participou do Conclat sem presença efetiva dos camaradas alagoanos. ${ }^{57}$

Mesmo admitindo a sua pouca representatividade junto à classe trabalhadora desses dois ENCLAT's ${ }^{58}$ e uma "manipulação dos encontros por parte do PCdoB", foi considerado um erro tático a não participação mais efetiva. No $2^{\circ}$ ENCLAT, a opção por privilegiar a questão eleitoral em detrimento desse encontro foi prejudicial $e$ custou caro, pois o PCB não tinha influência na Intersindical-Alagoas. A falta de um plano de trabalho para o movimento sindical, a inexistência de um trabalho no

\footnotetext{
57 "BALANÇO Histórico", p. 33.

${ }^{58}$ Os Encontros da Classe Trabalhadora - ENCLATs foram eventos estaduais cujo objetivo principal era a eleição de delegados para a participação no Congresso Nacional das Classes Trabalhadoras CONCLAT, o qual aconteceu em agosto1983. Foi neste evento que foi criada a Central Única dos Trabalhadores - CUT. Sobre o sindicalismo brasileiros nos anos 1980 e a criação da CUT, ver: BOITO Jr., Armando [et. al.]. O Sindicalismo brasileiro nos anos 80. Rio de Janeiro: Paz e Terra, 1991.
} 
movimento do campo só eram brevemente atenuadas na modesta atuação nas Associações de Moradores. No movimento estudantil, eram uma pequena força.

Esse ritmo lento do crescimento do Partido devia-se, sobretudo, a uma não definição de plano de trabalho. Plano detalhado com tarefas distribuídas de forma objetiva e com uma cobrança feita de forma regular. Não existia no Partido, por parte da direção, uma definição clara dos diversos níveis em que pessoas com uma maior ou menor ligação com a organização pudessem trabalhar. Urgia definir o trabalho de direção, suas funções específicas, quem era militante do Partido, quem era aliado $e$ quem era simpatizante.

Segundo o "Balanço...", teria sido mais fácil se o PCB tivesse condições de enviar para Alagoas algum militante experiente, para que orientasse na organização do Partido no estado. A cisão da direção nacional (Prestes versus Comitê Central) trazia problemas internos, ainda que não atingisse o nível de outros estados. De acordo com o documento "companheiros mais experientes, com vivência inclusive em outros Centros, se escudam nas divergências com a direção nacional para não dar uma contribuição mais efetiva" 59 .

Outro impasse residia na espécie de autogestão vivida àquela altura: cada militante gerenciava sua própria participação política $e$, essa situação impedia "uma maior disciplina e a prática da crítica e da autocrítica" ${ }^{60}$. Em agosto de 1982 foi realizada a Conferência cujo objetivo era debater e aprovar as teses do VII Congresso do PCB, além de eleger uma nova direção. Apenas um artigo saído de Alagoas, e escrito por um simpatizante, foi publicado no Caderno de Debates, o que já demonstra a ínfima intervenção. Os debates sobre as teses foram travados ligeiramente durante a realização da Conferência, refletindo o nível político ainda pouco desenvolvido.

A preparação e a realização da Conferência $e$, num segundo momento, a eleição da nova direção e do delegado ao VII Congresso foram marcadas pelo clima do período eleitoral das eleições estaduais de 1982. A direção eleita teve a tarefa de pegar o bonde eleitoral correndo: acabou por não atuar - talvez não saber - como direção, muita improvisação e pressa. A eleição de 15 de novembro foi, porém, uma lição de aprendizado profundo, conquanto se pudesse tirar dessa lição os ensinamentos necessários.

O primeiro era não repetir a atuação dos meses que antecederam a eleição, quando o Partido se dissolveu na frente política (PMDB) e não conseguiu dirigir efetivamente os trabalhos do Comitê Eleitoral dos seus candidatos. A incapacidade de combinar o trabalho do Partido com o do Comitê, tornando alguns militantes reticentes em participar da campanha. Apenas o trabalho organizado no PMDB jovem refletiu algum espirito de organização.

Outra imprecisão foi não priorizar áreas de atuação. Em vez de um trabalho nas maiores concentrações urbanas, onde existia uma relativa tradição de trabalhos organizados principalmente na grande Maceió (Rio Largo, Barra de Santo Antônio, Pilar, Satuba, Santa Luzia, Coqueiro Seco e Marechal Deodoro), foram investidos recursos humanos e financeiros de forma demasiada em municípios pequenos $e$ distantes, recursos que, se alocados com maior acerto, tornariam diferente o

59 "BALANÇO Histórico", p. 35.

60 "BALANÇO Histórico", p. 35. 
resultado. Ainda assim houve aspectos positivos no lançamento da candidatura de um membro do Partido a deputado estadual: Nilson Miranda. Era uma candidatura do Partido. Esse fato evidentemente, acabou por atrapalhar o já dificultoso trabalho, dado que o anticomunismo ainda era uma arma facilmente manejada, e de uma precisão quase cirúrgica.

Esse aspecto positivo não atenuaria o fato de não se ter sabido avaliar corretamente o nível de forças. Afinal, propuseram-se a participar de uma campanha sem a estrutura $e$ a experiência as quais contribuiriam para sair com resultado positivo, concorrendo com vários candidatos com discursos parecidos e contra o poder financeiro dos demais candidatos. O fator inexperiência os levou a aceitar, sem discussão profunda, o lançamento de candidaturas. As alianças refletiram mais a opinião pessoal do candidato pecebista a deputado estadual que a iniciativa conjunta do Partido, refletindo assim o personalismo reinante nesse período. Faltou habilidade, como Partido, para tirar proveito do espaço que se abriu durante os seis meses de campanha. Não houve crescimento da organização, não foi feito um trabalho de finanças nem se ampliaram e/ou se melhoraram os contatos. Nesse aspecto, não se pode contar com um órgão de imprensa, nem aproveitar o espaço criado pela Tribuna de Alagoas. O veículo de imprensa do Partido tinha uma natural dificuldade: era um jornal identificado publicamente como porta-voz do PCB, era feito para o público interno, $e$ isso tornava difícil o trabalho de massa, já que não havia um jornal de agitação. Concorrendo com outros jornais alternativos, se sofria desvantagens, já que a Voz trazia textos longos, de análises com poucas matérias de fácil leitura.

O resultado final acabou por demonstrar uma posição pouco cômoda. Isso devido à política de alianças se revelar muito estreita. Como o voto era vinculado, era necessário um maior número de candidatos a vereador, seja na capital ou no interior, mobilizados para a tarefa principal, que era eleger o deputado estadual do Partido. Apesar disso, a votação final representou em parte, na avaliação do documento, um voto consciente em um candidato comunista. A eleição do jornalista Freitas Neto, um aliado do $\mathrm{PCB}$, a vereador na capital trazia uma chance de se ter alguém de identidade quase completa com o projeto político comunista, abrindo o horizonte para a realização de um trabalho nos bairros da capital, assim como no movimento sindical urbano.

O documento conclui que o comitê eleitoral não funcionou corretamente, não sabendo atrair parcelas da juventude ávida de participação. Um espirito de clube familiar predominou nas discussões políticas internas. Os sentimentos pessoais passavam por cima da análise política concreta. No período pré-eleitoral, foi descartada a possibilidade de trabalho comum com outras candidaturas. Candidatos de posições políticas avançadas poderiam ter tido apoio crítico dos pecebistas ${ }^{61}$.

Terminando o balanço, a palavra de ordem residia na necessidade de organização. A sede provisória do jornal, onde estaria concentrado o centro de atividades fora recém estabelecida. Em seguida, organizar uma biblioteca, onde os diversos textos editados, que tivessem afinidade com o trabalho, estivessem à disposição do conjunto de militantes do Partido. Até então, o material bibliográfico (livros, revistas e jornais) era comprado, lido e guardado pelos membros em suas bibliotecas particulares.

61 "BALANÇO Histórico", p. 37.

SAECULUM - Revista de História [36]; João Pessoa, jan./jun. 2017. 
A definição da sede consistia num avanço, dado que o nível político da organização poderia tomar um impulso com promoções de cursos teóricos (sobre o movimento operário, economia política, filosofia, filosofia marxista etc.) e outras atividades que contribuíssem na melhoria na capacidade de análise e intervenção. A sede permitiria também desenvolver trabalho em dois outros setores vitais do Partido. Primeiro, o trabalho feminino. O PCB tinha várias militantes que mantinham uma relação de expectativa. Não estavam organizadas efetivamente pelo simples fato de não se ter tomado a iniciativa de reuni-las. Durante a campanha eleitoral, esse tipo de trabalho ficou impossibilitado de ser posto em prática pelas exigências de outras tarefas. Por fim, outro setor que merecia atenção especial era o juvenil. A definição de uma política em relação à juventude se tornava latente. Tarefas específicas dos jovens deveriam ser realizadas pelos membros da juventude do Partido. A tarefa consistia na criação de canais de participação num setor onde havia amplas possibilidades de trabalho.

Expectativa e esperança. Baque e decepção. Extremos que estarão presentes em todos os documentos produzidos a partir de então. De um lado, um ânimo que se queria inabalável na capacidade de trabalho, na força da organização, no potencial transformador da agremiação cuja atuação pretérita a tornara a principal força de esquerda em Alagoas antes da instauração da Ditadura; do outro lado, o choque com a realidade presente, cujo ritmo de transformações se acelerava e impunha respostas imediatas às quais os comunistas ainda não estavam em condições - ou quem sabe, não estavam mais - de dar.

\section{Considerações Finais}

O processo de abertura política, intensificado depois da Lei de Anistia em 1979, permitiu a reorganização PCB no país. Até 1985 , quando conseguirá legalização definitiva, o partido se manteve sob as asas do (P)MDB, atuando abertamente na sociedade brasileira sem, no entanto, deixar de ser alvo da repressão da Ditadura ainda vigente. Junto a isso, presenciou em 1980 o rompimento de Luís Carlos Prestes, Secretário Geral da instituição desde a década de 1940. A linha política a qual deu o norte da atuação pecebista ao longo década apostava na formação de uma frente única capaz de isolar e derrotar o Regime Militar.

Em Alagoas, com a volta do exilio de Nilson Miranda, o partido conseguiu se reorganizar contando com alguns dos militantes atuantes no PCB antes de 1964 juntamente com uma geração de jovens oriundos do movimento estudantil. A partir das eleições de 1978, da campanha pela Anistia em 1979, os comunistas alagoanos participarão de uma série de movimentos políticos com o objetivo de superar a Ditadura, dos quais as eleições de 1982 e as Diretas Já serão os pontos máximos de mobilização.

Ainda assim, mesmo o empenho na luta pela redemocratização do país não será capaz de deter a tensão paulatinamente acirrada no âmbito do PCB alagoano. Duas gerações, com formações e culturas políticas diferenciadas, se encontrarão em um impasse no que diz respeito às ações prática da agremiação.

\section{8}




\section{RESUMO}

O objetivo deste artigo é analisar a reorganização do PCB em Alagoas entre 1980 e 1982. A atenção recairá inicialmente nos dois processos paralelos que envolveram, de um lado, a reorganização do Partido em nível nacional, com o retorno do Comitê Central, o qual se encontrava exilado desde meados da década de 1970; de outro, as estratégias adotadas pelos comunistas alagoanos para a reestruturação da agremiação no estado. Antes da profunda atuação na campanha pela Anistia, as articulações para as eleições legislativas de 1978 foram um marco no trabalho da militância pecebista alagoana, ao mesmo tempo em que possibilitaram a entrada de um grupo de jovens estudantes os quais, juntamente com os antigos comunistas deram o passo decisivo para restabelecer a atuação política do Partido em Alagoas a partir do ano de 1980.

Palavras Chave: Partido Comunista Brasileiro; Ditadura Militar; Anistia.

Artigo recebido em 29 mai. 2016.

Aprovado em 06 dez. 2016.
The aim of this paper is to analyse the reorganization of the Brazilian Communist Party in the State of Alagoas, between 1980 and 1982. The focus will be initially in two parallel processes involving, the one hand, the Party's reorganization at national level, with the return of the Central Bureau, which was in exile since the mid-1970s; the other, the strategies adopted by communists in Alagoas for the restructuring of the association in the state. Before the profound role in the campaign for Amnesty, the joints for the 1978 parliamentary elections were a milestone in the work of local communist militancy, while that allowed the entry of a group of young students who, along with former communist gave the decisive step to restore the Party's political activity in Alagoas from 1980.

Keywords: Brazilian Communist Party; Military Dictatorship; Amnesty. 